Florida International University FIU Digital Commons

11-17-1999

\title{
Factors affecting growth and survival of snowy egret nestlings
}

Lisa Borgia

Florida International University

DOI: $10.25148 /$ etd.FI14051196

Follow this and additional works at: https://digitalcommons.fiu.edu/etd

Part of the Biology Commons

\section{Recommended Citation}

Borgia, Lisa, "Factors affecting growth and survival of snowy egret nestlings" (1999). FIU Electronic Theses and Dissertations. 1734. https://digitalcommons.fiu.edu/etd/1734

This work is brought to you for free and open access by the University Graduate School at FIU Digital Commons. It has been accepted for inclusion in FIU Electronic Theses and Dissertations by an authorized administrator of FIU Digital Commons. For more information, please contact dcc@fiu.edu. 


\section{FLORIDA INTERNATIONAL UNIVERSITY}

Miami, Florida

\section{FACTORS AFFECTING GROWTH AND SURVIVAL OF SNOWY EGRET NESTLINGS}

A thesis submitted in partial fulfillment of the requirements for the degree of MASTER OF SCIENCE in

BIOLOGY

by

Lisa Borgia

1999 
To: Dean Arthur W. Herriott

College of Arts and Sciences

This thesis, written by Lisa Borgia, and entitled Factors Affecting Growth and Survival of Snowy Egret Nestlings, having been approved in respect to style and intellectual content, is referred to you for judgment.

We have read this thesis and recommend that it be approved.

Joel Trexler

Daniel Childers

Victor Apanius, Major Professor

Date of Defense: November 17, 1999

The thesis of Lisa Borgia is approved.

Dean Arthur W. Herriott
College of Arts and Sciences

Florida International University, 1999 


\section{DEDICATION}

To my son, Julian. 


\section{ACKNOWLEDGEMENTS}

I wish to thank the members of my committee for their patience and guidance.

Dr. Dan Childers offered me support and confidence when most needed. Dr. Joel Trexler provided firm direction and belief in my ability to complete this work. Dr. Victor Apanius pushed me to not just produce a thesis, but to have pride in my finished product.

I would also like to thank the members of the wading bird research community. I received help and guidance without reserve from everyone I consulted and was made to feel I had something valuable and important to say. 
ABSTRACT OF THE THESIS

\section{FACTORS AFFECTING GROWTH AND SURVIVAL \\ OF SNOWY EGRET NESTLINGS}

by

\section{Lisa Borgia}

Florida International University, 1999

Miami, Florida

Professor Victor Apanius, Major Professor

It is widely believed that wading birds in the Everglades have declined as a result of historic water management practices. I determined growth rates for Snowy Egret (Egretta thula) chicks by assessed the nestling body condition through measurement of body weight and skeletal traits. A growth index was calculated as a residual of body weight regressed on age. A body condition index was calculated as the residual of body weight regressed on a skeletal trait (tarsus). Growth was significantly related to water level and hatch date. Survival rates were calculated to day 14,21 , and 50. Survival to 50 days of age was significantly related to hatch date and order. Survival to 21 days of age was significantly related to water level and hatching order. Survival to 14 days of age was marginally related to hatching order. Growth and survival is greatly influenced by water level and hatch date. 


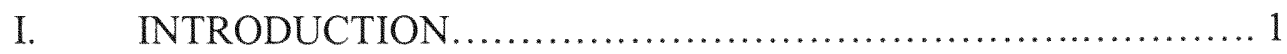

II. METHODOLOGY......................................... 4

Field procedures.............................................. 5

Analytical procedures.......................................6 6

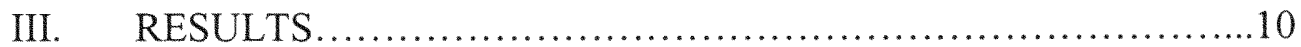

Water Level and Year Effects...................................10

Growth.................................................... 14

Survival................................................ 17

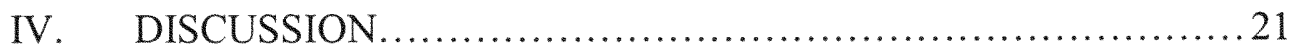

LIST OF REFERENCES ..........................................25 


\section{LIST OF TABLES}

TABLE

PAGE

1. Dependent Variable: Water Level......................................11

2. Dependent Variable: Hatch Date.........................................11

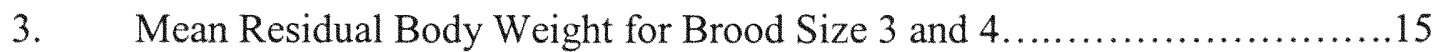

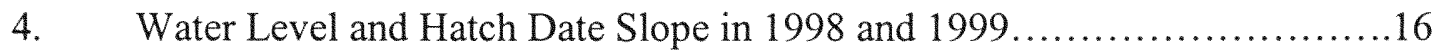

5. Survival Probability for Brood Size 3 and 4 by Order.....................19 


\section{LIST OF FIGURES}

FIGURE

PAGE

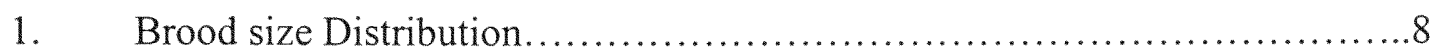

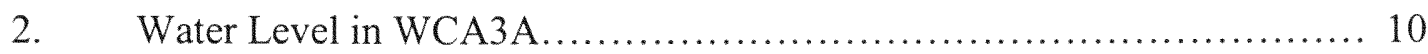

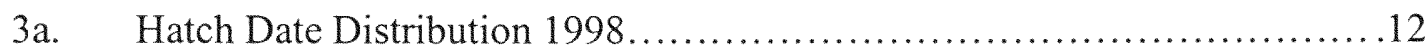

3b. Hatch Date Distribution 1999..................................... 12

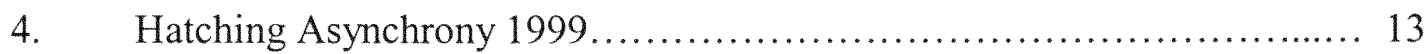

5. Mean Residual Body Weight 1998 Broodsize 3 and 4 ................ 15

6a. Survival to 14 Days of Age Broodsize 3 and 4 by Order.................. 19

6b. Survival to 21 Days of Age Broodsize 3 and 4 by Order.................. 20

6c. Survival to 50 Days of Age Broodsize 3 and 4 by Order................. 20 


\section{INTRODUCTION}

The Snowy Egret (Egretta thula) was a common nesting species throughout Florida, along the coast of the Gulf of Mexico, and on the Atlantic coast prior to the plume-hunting era (ca. 1880-1910) in the United States (Scott 1887, Bent 1926). Subsequently, the Snowy Egret was extirpated or became rare in most of its former U.S. range (Scott 1887, Bent 1926). The species in Florida recovered, apparently to reach peak numbers between the 1930s and early 1950s (Sprunt 1954, Robertson and Kushlan 1974, Ogden 1978), after which the number nesting declined, possibly at a more rapid rate than other small ardeids (Robertson and Kushlan 1974). The number in the traditional Everglades colonies recovered to an estimated 10,000 pairs by the 1930s; by the middle to late 1970s the number in Everglades colonies had declined to 4,500 pairs and by the late 1980s to 1,500 pairs (Frederick and Collopy 1988, Ogden 1994).

Several studies on Snowy Egret demography have been conducted in Florida. For example, Bancroft et al. (1990), Frederick (1993), Frederick (1995), Jenni (1969), and Strong et al (1997) have studied foraging strategy, nesting phenology, and reproductive ecology for this species in Florida. However, most information concerning the growth and survival of Snowy Egret chicks has largely been limited to studies on the Atlantic coast (Erwin et al. 1996, St. Claire Raye and Burger 1979) or North America in general (Ryder 1978). Because the impounded remnant Everglades has a much different hydrologic pattern than that of coastal areas, I began a study of 
colonies to examine possible reasons why the breeding population of Snowy Egrets is still declining in this area.

At present, the factors responsible for reduced reproductive success in wading birds have not been identified (Cezilly 1997). Heavy metal toxicity, parasites, and changes in hydrology that adversely impact the prey fish base are all possible factors (Frederick and Spalding 1994). A critical step in the linkage of trophic levels (e.g., fish prey and avian predators) is the reproductive response of predators to varying prey vulnerability and availability. Research with other avian predators (e.g., raptors) has shown that responses follow one of several strategies. One group of taxa is nomadic opportunistic breeders, with large clutch size, long juvenile dispersal distances, and high variance in lifetime reproductive success. Strongly territorial species exhibit drastic diet shifts and occasionally suppress reproduction during low prey availability (Beissinger and Takekawa 1983). Parallel strategies can be found in species assemblages of wading birds, which are highly variable in their reproductive strategies (Bancroft and Jewell 1987, Frederick and Collopy 1989b).

Asynchronous hatching is common in birds that exploit unpredictable and seasonally and /or greatly changeable food resources (Lack 1954, 1966). Hatching asynchrony depends on egg laying intervals and onset of incubation and that in turn establishes competitive disparities within individual broods (Inoue 1985). Wading birds use this life history strategy, and Snowy Egrets chicks are assumed to hatch in two-day intervals (Baicich and Harrison 1997), as do Cattle Egrets (Bubulcus ibis) (Fujioka 1984). Currently, changing water levels (and the implied reduction in prey 
availability) are cited as driving the declines in breeding populations of wading birds in the Everglades (Bancroft and Jewell 1987).

The dynamics of an animal population are the result of a balance between mortality and recruitment. Whether for fundamental or for applied goals an appropriate understanding of survival patterns is one the keys to animal biology (Lebreton et al. 1993). Food supply ultimately limits individuals and populations; however, many ecological factors can act to reduce the proximate importance of food supply. A continuing controversy exists relating the role that food supply plays in shaping the patterns of life history, population dynamics and community structure we see in nature (Lack 1954, Hairston et al. 1960, Weins 1977, Arcese and Smith 1988, reviewed in Boutin 1989). The Everglades wading bird breeding population provides an opportunity to examine the dynamics of food supply, survival, and recruitment in assessing these theoretical constructs.

The most extensively studied demographic parameter for the Everglades wading bird population has been nesting attempts. Wading bird reproductive success provides a conceptual framework for utilization of indicator species in ecosystem restoration (Custer and Osborn 1977). The breeding population of wading birds historically has been used as an indicator of the health of the Everglades ecosystem. Reproductive success measurements allow the investigator to assess the stability of a population and enable comparisons to be made among or within populations (Erwin and Custer 1982). However, it may be that annual variation in breeding attempts is of relatively less importance than juvenile survival rates in measuring the health of the 
ecosystem. Measures of breeding success are often unreliable, with colony productivity often equated with fledgling success without considering the quality or longevity of the fledged chicks. Cezilly (1995) showed a correlation between the average body condition of chicks and the extent of flooded surface in the unstable part of the foraging habitat, thus bridging the gap between hydrology and fledging success rates. Cezilly (1997) also considers annual variations in breeding success to be of relatively small importance and calls for further studies regarding the co-variation between productivity and chick quality in wading birds.

In this research, I examined the growth and survival of Snowy Egret chicks to test three hypotheses: (1) Differential survival and growth rates occurs between broods hatched throughout the breeding season; i.e., early hatch date broods have a higher survival and growth rate than late hatch date broods; (2) Differential growth and survival of chicks occurs within broods of larger size; i.e., larger broods have lower growth rates and lower survival rates than smaller broods; (3) Differential growth and survival of chicks occurs within broods; i.e., chicks that hatch first have higher growth rates and higher survival rates than younger siblings.

\section{STUDY SITES AND METHODS}

I studied Snowy Egrets at a breeding colony located in the remnant Everglades, specifically Water Conservation Area (WCA) 3A, in Miami-Dade County, Florida, $\left(25^{\circ} 46.615^{\prime} \mathrm{N} 080^{\circ} 50.340^{\prime} \mathrm{W}\right)$ during 1998 and 1999 . The colony site (referred to as "Hidden Colony") was a mixed species colony composed of Great Egrets 
(Casmerodius albus), Little Blue Herons (Egretta caerulea), and Tricolor Herons

(Egretta tricolor), as well as Snowy Egrets. The colony was located in a cypress strand at the southwest corner of WCA $3 \mathrm{~A}$, in close proximity to the junction of Everglades National Park, Big Cypress Preserve, and the impounded remnant Everglades. The number of adults using the colony varied between years, but the general location of the nest sites remained consistent. Water level data from Army Corps of Engineer gauges $(63,64$, and 65), that monitor water levels in WCA 3A, were used to determine daily mean water level. These gauges are located to the east and north of the colony, with the closest (65) located approximately $8 \mathrm{~km}$ to the east.

\section{Field Procedures}

To reduce investigator disturbance, the colony was visited only once after the onset of incubation to determine clutch size. The sampling protocol thereafter restricted visitation to no more than once every 3 days after hatching. Nests were chosen at random for both years, specifically 20 nests in 1998 and 50 nests in 1999 . Each nest was tagged and the fate of each chick followed until the chick had died, dispersed, or was too mobile to capture and measure.

The colony was visited every 3-4 days in 1998 and every 3 days in 1999 to monitor chick hatching, growth, and survival. On each visit, the nest area was thoroughly searched and any sick, dying, or missing chicks were noted for later calculation of survival. New chicks were marked with temporary colored bands and were later banded with standard aluminum US Geological Survey bands when the 
tarsus reached sufficient size (10-14 days). Clutch size and the number of chicks were recorded for each nest.

Growth parameters of the chicks were measured using standard procedures. Mass was measured (nearest $1 \mathrm{gr}$.) with a Pesola spring scale. Culmen length was measured (nearest $0.1 \mathrm{~mm}$ ) from the tip of the bill to the back of the skull and tarsometatarsus length was measured (nearest $0.1 \mathrm{~mm}$ ) from joint to base of the first toe.

\section{Analytical Procedures}

Each chick was assigned an alpha code when it hatched, based on hatch order: A-chick $=$ first hatched, B-chick $=$ second hatched, $\mathrm{C}$-chick $=$ third hatched, and Dchick $=$ fourth hatched. When the hatch date was unknown (designated Day 0), it was estimated from the weight, skeletal measurements, and the known age of any siblings.

Radio transmitters (approximately 5 gr.) with mortality switches (Holohil Systems, Ltd.) were attached to chicks when they reached a sufficient body weight (200-250 gr.). Transmitters were attached to 19 chicks in 1998 and 12 chicks in 1999 using a backpack arrangement. Backpacks were manufactured using a chamois pad to protect the chick. A single cotton thread stitch was used to attach the straps, allowing the transmitter to eventually fall off. A $151-153 \mathrm{MHz}$ radio receiver (Advanced Telemetry Systems) was used to follow these chicks until death or dispersal at approximately 45-60 days of age. Transmitters were recovered from dead chicks and reused. 
To evaluate temporal effects on nest success and chick growth, I used the continuous variable of day hatched (hatch date). I also used a "standardized hatch date" which represented the number of days after the first chick hatched in that breeding season, i.e., hatch date-first chick hatch date $=$ standardized hatch date. For example, the chicks hatched on the first day in either year have a standardized hatch date of zero, chicks hatched on the second day have a standardized hatch date of one, and so on. This method allowed more powerful comparison of between year effects by comparing relative hatch dates for each breeding season.

Because chicks were not measured daily, or at regular intervals in 1998, I could not calculate complete growth curves for individual chicks. A mean residual was determined from the regression of the body weight, tarsus, and culmen curve of each chick to age. The regression of all chicks' body weight $\left(r^{2}=0.9484\right)$, $\operatorname{tarsus}\left(r^{2}\right.$ $=0.9752)$, and culmen $\left(r^{2}=0.9835\right)$ was used to produce the mean residual values. A body weight growth index was calculated as a residual of body weight regressed on age. A body condition index was calculated as the residual of body weight growth index regressed on the residual of a skeletal trait (tarsus, $r^{2}=0.6155$ ). Both indices were then compared to determine any categorical effects on growth (i.e., water level, year, hatch date, brood size, and hatch order). All water level analyses were based on daily mean water levels from gauge 65 , located $8 \mathrm{~km}$ from the colony.

All statistical analyses were performed with SAS (SAS 1994). The regression lines and slopes for the growth data were produced with the REG Procedure. Analysis of variance (GLM Procedure) using body weight growth and body condition indices 
identified any water level, year, hatch date, brood size, and hatch order effects on chick growth.

I monitored clutch size and hatching interval at 70 nests (20 in 1998 and 50 in 1999), that contained Snowy Egrets and hatched at least one young (Fig. 1). Chicks that had two or more data points within the breeding season were used in all analyses $(\mathrm{N}=197)$. Brood sizes of 1,2 , and 5 had a small sample size $(2,9$, and 3 , respectively for both years combined) and were dropped from further analyses. When comparing effects on broods of 3 and 4 , "D" chicks were sometimes eliminated to maintain balanced analyses.

Figure 1. Brood Size Distribution for All Broods 1998 and 1999.

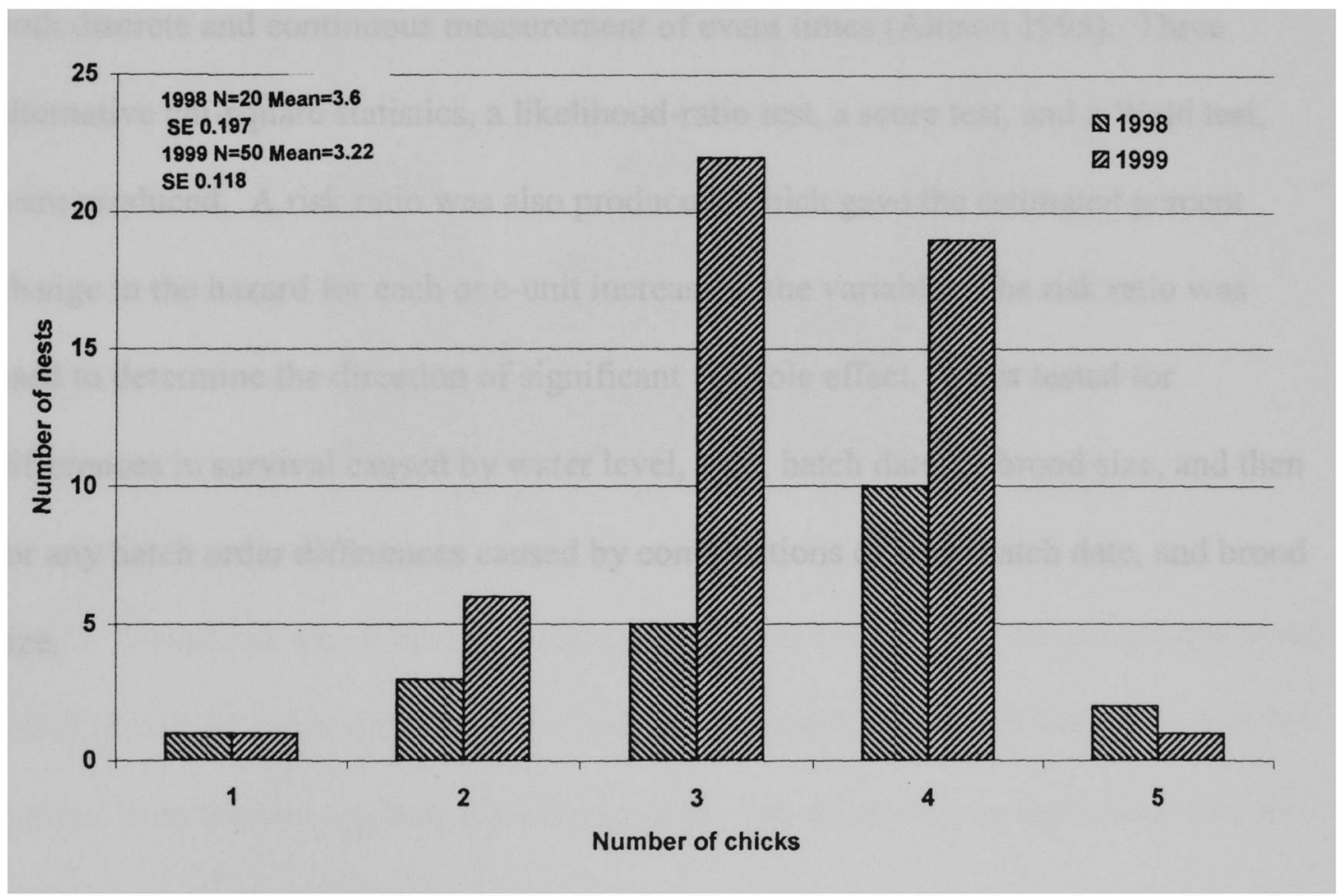


I examined chick survival to 14,21 , and 50 days of age. Chicks that were found dead or were missing before age 14,21 , or 50 days were recorded as dead or missing on that visit. Chicks recorded as missing prior to 14,21 , or 50 days of age were 'censored' (see LIFETEST Procedure in SAS 1994). Survival probabilities were calculated using LIFETEST Procedure in SAS, which calculates Kaplan-Meier probabilities of survival through time, incorporating any 'censored' data, and calculates a log rank statistic (Lawless 1982) to test for homogeneity among the categorical variables.

Survival analyses were done using the PHREG Procedure in SAS, which implements Cox regression, a semiparametric method. This method permits a stratified analysis, which incorporates time-dependent variables that can be used for both discrete and continuous measurement of event times (Allison 1995). Three alternative chi-square statistics, a likelihood-ratio test, a score test, and a Wald test, were produced. A risk ratio was also produced, which gave the estimated percent change in the hazard for each one-unit increase in the variable. The risk ratio was used to determine the direction of significant variable effect. I first tested for differences in survival caused by water level, year, hatch date, or brood size, and then for any hatch order differences caused by combinations of year, hatch date, and brood size. 


\section{RESULTS}

Water Level and Year Effect

To characterize exogenous factors, I conducted preliminary analyses on the effects of water level and year. Water levels varied between years by date $\left(\mathrm{F}_{1,223}=\right.$ 95.44, $\left.\mathrm{P}<0.0001, \mathrm{r}^{2}=0.3007\right)$. The combined water level data from gauges 63,64 , and 65 (Fig. 2) clearly show the water level to be different on any given date between years and demonstrates how the timing of the breeding season was related to hydrologic patterns.

Figure 2. Water Level for Water Conservation Area 3A 1998-1999 ${ }^{\mathrm{a}}$.

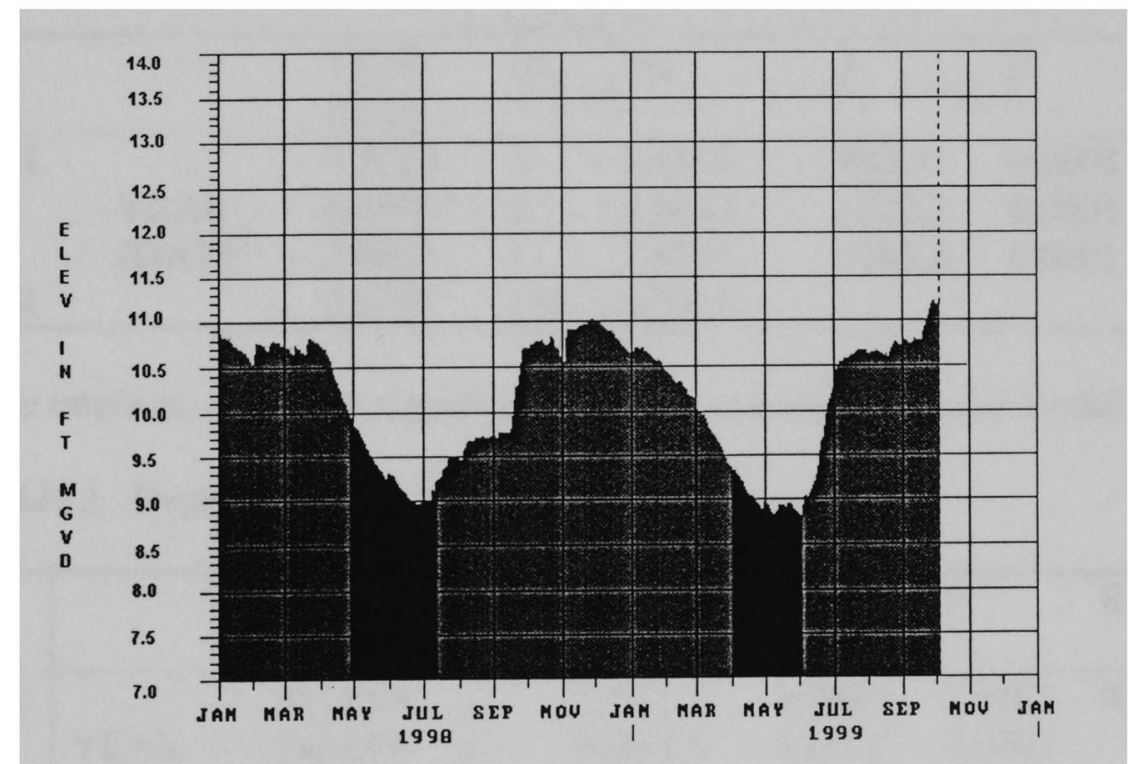

${ }^{a}$ Note: the elevation represented is the mean elevation of the gauges above sea level ( $8.067 \mathrm{ft}$.), plus surface water. The shaded areas between the lines represent the period from the first egg being hatched and the last chick leaving the colony area as followed by radio telemetry. 
The rate of drydown did not differ between the 1998 and 1999 breeding periods, as the year by Julian date interaction was not significant. Therefore, significant Julian date and year effects on water level (Table 1) suggest parallel rates of drydown between the breeding periods. The water level during the breeding period was $0.7920 \mathrm{ft}$. higher in 1998 as compared to 1999 , with a combined drydown rate during the breeding period of $0.1468 \mathrm{ft}$ per day for both years. The hatch date of the first chick varied significantly between years (Fig. 3). After adjusting for difference between years, water level was significantly related to the hatch date (Table 2).

Table 1. Dependent Variable: Water Level ${ }^{\mathrm{a}}$

\begin{tabular}{llllllll}
\hline Source & & TYPE & df & MS & F & P & $\mathrm{R}^{2}$ \\
& & III SS & & & & & \\
\hline MODEL & & 4.3289 & 2 & 2.1644 & 895.3 & 0.0001 & 0.890 \\
& YEAR & 4.2846 & 1 & 4.2846 & 1772.3 & 0.0001 & \\
ERROR & JDATE & 2.8667 & 1 & 2.8667 & 1185.8 & 0.0001 & \\
\hline
\end{tabular}

${ }^{a}$ Note: the interaction was not significant and was excluded from the model.

Table 2. Dependent Variable: Hatch Date ${ }^{a}$

\begin{tabular}{l|lllllll}
\hline Source & & $\begin{array}{l}\text { TYPE } \\
\text { III SS }\end{array}$ & df & MS & F & P & $\mathrm{R}^{2}$ \\
& & & & & & \\
\hline MODEL & & 95150.4 & 2 & 47575.2 & 2749.9 & 0.0001 & 0.9614 \\
& YEAR & 94249.6 & 1 & 94249.6 & 5447.7 & 0.0001 & \\
& WL & 20515.6 & 1 & 20515.6 & 1185.8 & 0.0001 & \\
ERROR & & 3823.5 & 221 & 17.301 & & & \\
\hline
\end{tabular}

${ }^{a}$ Note: the interaction was not significant and was excluded from the model. 
Figure 3a. Hatch Date Distribution in 1998. Broods with 1, 2, or 5 chicks were excluded due to small sample sizes.

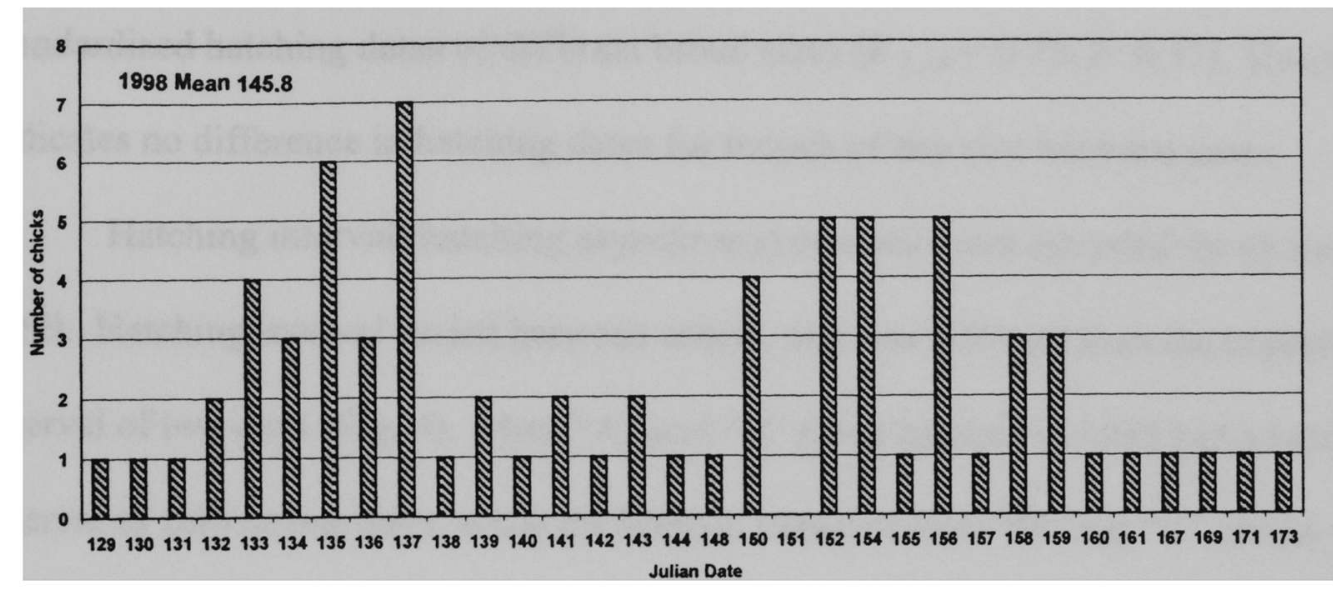

Figure 3b. Hatch Date Distribution in 1999. Broods with 1, 2, or 5 chicks were excluded due to small sample sizes.

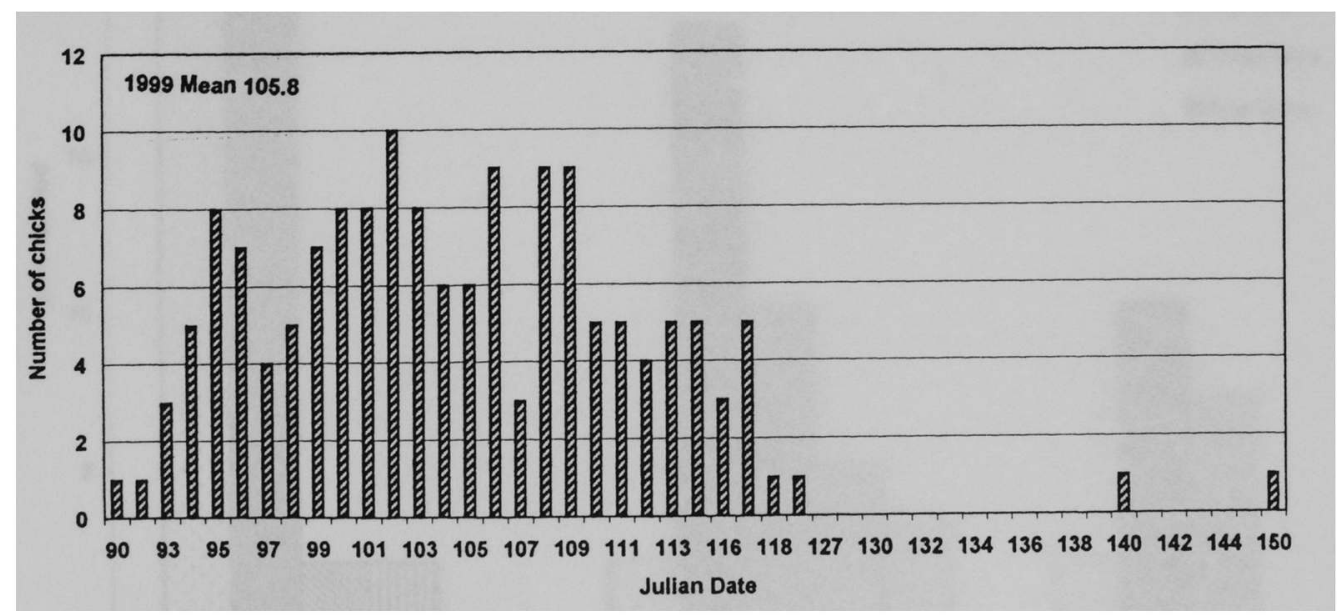


Brood size did not vary significantly between years $\left(X^{2}=6.21, \mathrm{P}=0.18\right)$, but the hatching dates of the first egg of each nest were significantly different between years $\left(\mathrm{F}_{1,68}=212.1, \mathrm{P}<0.0001, \mathrm{r}^{2}=0.76\right)$. There was no significant difference in standardized hatching dates of different brood sizes $\left(\mathrm{F}_{1,68}=0.73, \mathrm{P}<0.57\right)$. This result indicates no difference in hatching dates for broods of any size between years.

Hatching interval (hatching asynchrony) of chicks was recorded for all nests in 1999. Hatching interval varied between orders, and was different than the expected interval of two days (Fig. 4). Most "A" and "B" chick hatched in 1999 had a hatching interval of zero or one days, while the interval between most " $\mathrm{B}$ " and " $\mathrm{C}$ " chicks was one or two days.

Figure 4. Asynchrony of Hatching in 1999.

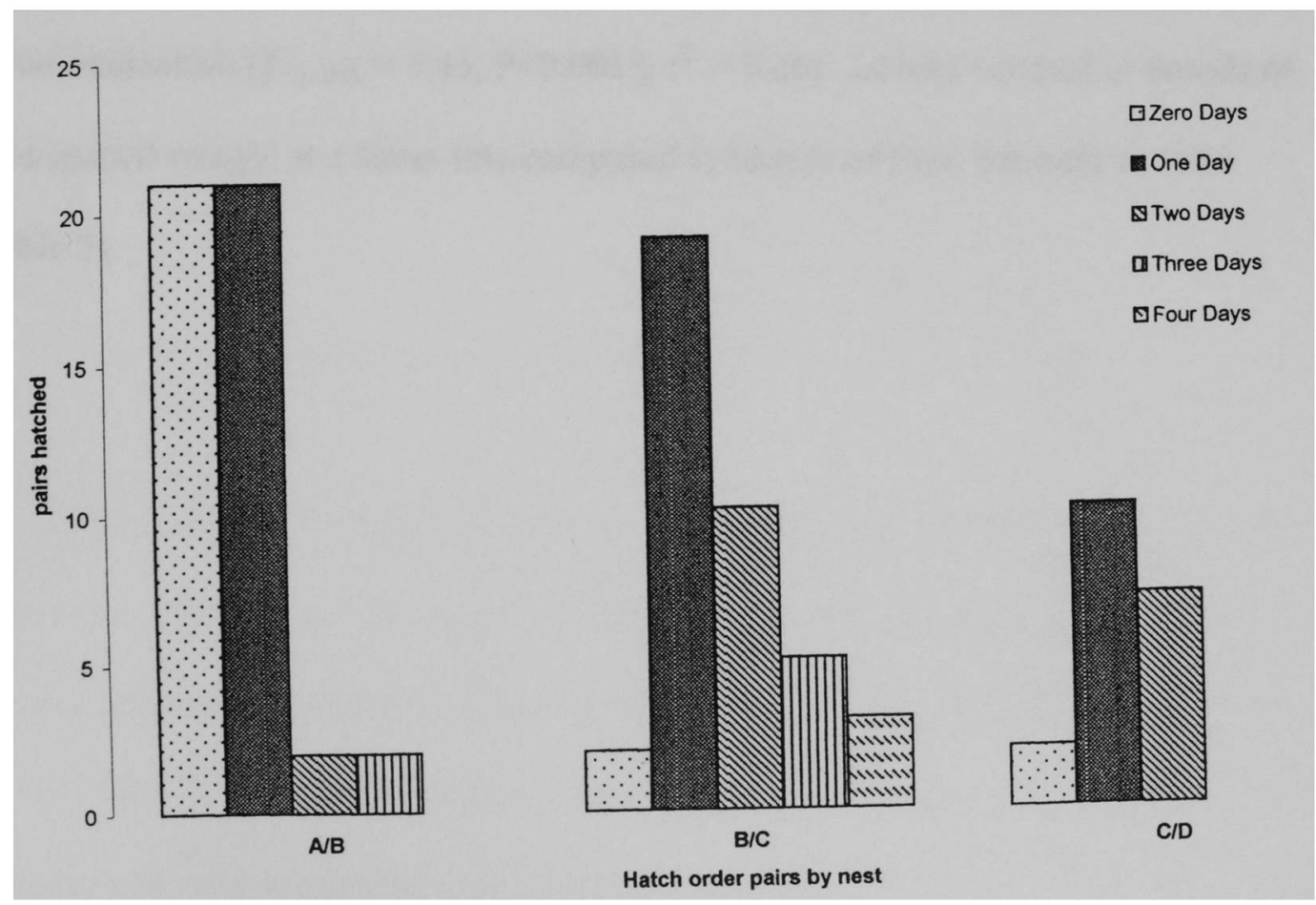




\section{Growth}

Using the mean residual body weight as an index of body weight growth, the year and water level interaction $\left(\mathrm{F}_{3,222}=16.66, \mathrm{P}<0.0001, \mathrm{r}^{2}=0.19\right)$ was found to be significantly related to chick growth. The body weight growth index was significantly related to the water level in $1998\left(\mathrm{~F}_{1,56}=34.36, \mathrm{P}<0.0001, \mathrm{r}^{2}=0.39\right)$ but not 1999 . Since water levels decreased as hatching dates were increasing, it would be expected that the hatch dates were related to body weight growth. Accordingly, body weight growth was significantly related to the year and hatch date interaction $\left(F_{3,192}=14.48\right.$, $\mathrm{P}<0.0001, \mathrm{r}^{2}=0.19$ ). The body weight growth index was significantly related to the hatch date in $1998\left(\mathrm{~F}_{1,58}=37.81, \mathrm{P}<0.0001, \mathrm{r}^{2}=0.39\right)$, but not in 1999. The negative relationship between hatch date and body weight growth was only significant in 1998 (Fig. 5). The body weight growth index was also significantly related to the year and brood interaction $\left(\mathrm{F}_{3,162}=5.45, \mathrm{P}<0.0013, \mathrm{r}^{2}=0.26\right)$. Chicks hatched in broods of three gained weight at a faster rate compared to broods of four, but only in 1998 (Table 3). 
Figure 5. Body Weight Growth in 1998. Growth is expressed as the averaged residual of the body weight and age regression. Only broods of 3 and 4 chicks were included.

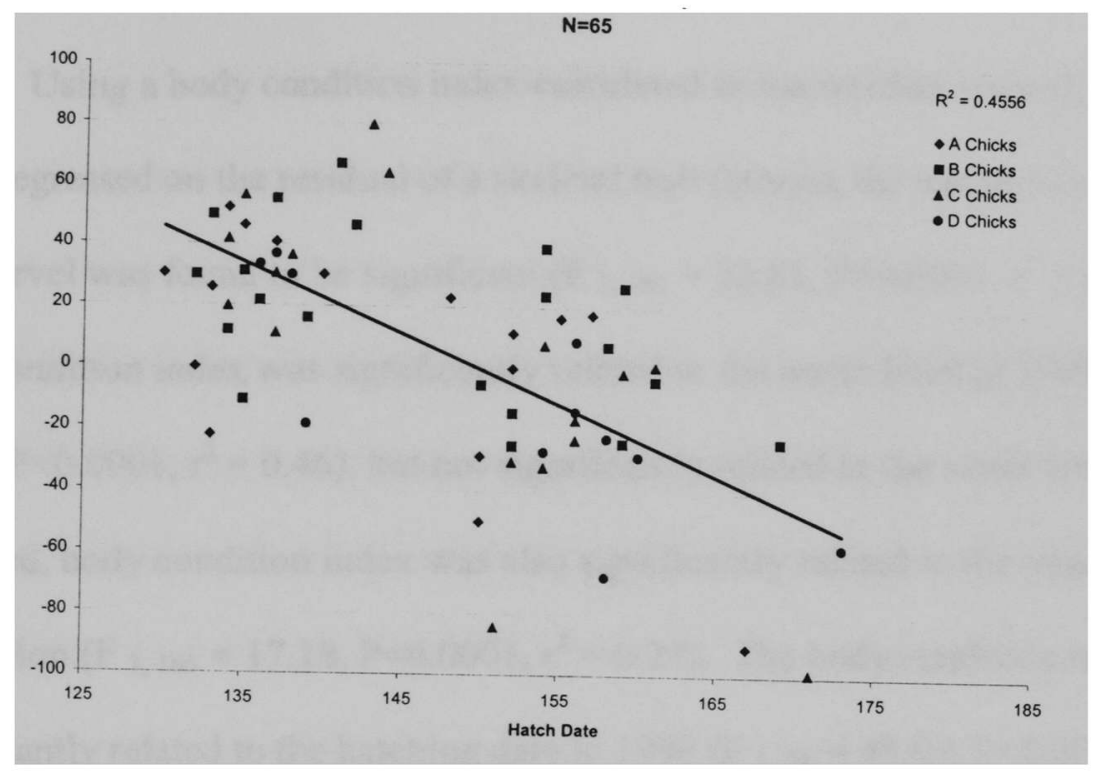

Table 3. Mean residual body weight for brood size 3 and 4 .

\begin{tabular}{llll}
\hline YEAR & BROOD SIZE & MRBWT & $+/-\mathrm{SE}$ \\
\hline 1998 & 3 & 24.6912 & $9.6537 \mathrm{~N}=16$ \\
1998 & 4 & -6.9074 & $5.2212 \mathrm{~N}=43$ \\
1999 & 3 & -3.2895 & $3.8149 \mathrm{~N}=61$ \\
1999 & 4 & 0.2771 & $2.8181 \mathrm{~N}=73$ \\
\hline
\end{tabular}

The effect of hatching order on the body weight growth index was examined in two ways: (1) Pooling broods of three and four but excluding the "D" chick; or (2) Conducting separate analyses of broods of 3 ("A", "B", and "C" chicks) and broods of 4 ("A", "B", "C", and "D" chicks). In the first analysis without "D" chicks, the effect of order was only marginally significant $\left(\mathrm{F}_{1,164}=3.75, \mathrm{P}<0.0546, \mathrm{r}^{2}=0.0225\right)$ for the 
body weight growth index. For broods of three chicks, the effect of hatching order was related to the body weight growth index for broods of 4 chicks $\left(F_{1,115}=3.98\right.$, $\left.\mathrm{P}<0.0337, \mathrm{r}^{2}=0.03\right)$

Using a body condition index calculated as the residual of body weight growth index regressed on the residual of a skeletal trait (tarsus), the interaction of year by water level was found to be significant $\left(\mathrm{F}_{3,185}=23.81, \mathrm{P}<0.0001, \mathrm{r}^{2}=0.28\right)$. The body condition index was significantly related to the water level in $1998\left(\mathrm{~F}_{1,56}=\right.$ $47.34, \mathrm{P}<0.0001, \mathrm{r}^{2}=0.46$ ), but not significantly related to the water level in 1999 . As expected, body condition index was also significantly related to the year by hatch date interaction $\left(\mathrm{F}_{3,160}=17.18, \mathrm{P}<0.0001, \mathrm{r}^{2}=0.24\right)$. The body condition index was significantly related to the hatching date in $1998\left(\mathrm{~F}_{1,58}=48.09, \mathrm{P}<0.0001, \mathrm{r}^{2}=0.46\right)$, but was not significantly related to the hatching date in 1999. The relationship between the water level and the hatching date between the two breeding seasons was very different for the body condition index (Table 4). Body condition index was not significantly related to brood size or the year by brood size interaction.

Table 4. Water level and hatch date parameter estimates in 1998 and 1999

\begin{tabular}{llll}
\hline YEAR & VARIABLE & SLOPE & $+/-\mathrm{SE}$ \\
\hline 1998 & WATER LEVEL & 178.972 & $30.5302 \mathrm{~N}=58$ \\
1999 & WATER LEVEL & 3.3327 & $1.1443 \mathrm{~N}=133$ \\
1998 & HATCH DATE & -2.244 & $0.3649 \mathrm{~N}=58$ \\
1999 & HATCH DATE & -0.1664 & $0.2529 \mathrm{~N}=133$ \\
\hline
\end{tabular}


Again, the effect of hatching order on the body condition index was examined by two methods: (1) Pooling broods of 3 and 4 but excluding the "D" chick; and (2) Conducting separate analyses of broods of 3 ("A", "B", and "C" chicks) and broods of 4 ("A", "B", "C", and "D" chicks). The effect of order was not significant for the body condition index in any of these analyses.

\section{Survival}

I monitored survival of chicks in 70 nests (20 in 1998 and 50 in 1999). The effect of the different variables was calculated using maximum likelihood estimates, and the direction of significant effects determined from the estimated risk ratio.

Survival from hatching to 14 days of age was not related to the water level, year, hatch date, standardized hatch date, or brood size. The hatch order alone was marginally significant $\left(X^{2}=3.05, \mathrm{P}=0.0806, \mathrm{~N}=189\right)$ and the risk of death increased for each consecutively hatched chick within an individual brood (Risk Ratio 1.396).

Survival from hatching to 21 days of age was significantly related to the water level on day of hatching $\left(X^{2}=4.16, \mathrm{P}=0.0414, \mathrm{~N}=192\right)$. As water levels on day of hatching decreased, the risk of death increased (Risk Ratio 0.069). Survival during the 0-21 day interval did not vary between years, however the hatching date was significant only after controlling for the year effect $\left(X^{2}=6.24, \mathrm{P}=0.0125, \mathrm{~N}=193\right)$. The risk of death increased for each day later in the breeding period a chick was hatched (Risk Ratio 1.033). Reasonably, the standardized hatch date alone was significant as well $\left(X^{2}=5.91, \mathrm{P}=0.0151 \mathrm{~N}=192\right)$. The risk of death increased for each day later in the breeding period a chick was hatched (Risk Ratio 1.045). Survival 
from hatching to 21 days of age did not differ between broods of different size, but survival rates were significantly related to the hatching order $\left(X^{2}=6.08, \mathrm{P}=0.0137\right.$, $\mathrm{N}=192$ ). The risk of death increased for each consecutively hatched chick within an individual brood (Risk Ratio 1.536).

Survival during the interval between hatching and 50 days of age varied between years. For survival to 50 days of age, the year effect was marginally significant $\left(X^{2}=2.79, \mathrm{P}=0.0946 \mathrm{~N}=190\right)$ with lower risk of death for chicks hatched in 1999(Risk Ratio 0.583). Survival from hatching to 50 days of age was significantly related to the water level on day of hatching after adjusting for the effect of year $\left(X^{2}\right.$ $=6.83, \mathrm{P}=0.0090 \mathrm{~N}=187$ ). As water levels on day of hatching decreased, the risk of death increased (Risk Ratio 0.036). Survival from hatching to 50 days of age was significantly related to date of hatching with increased risk of death as hatch date increased $\left(X^{2}=6.68, P=0.0098, N=190\right.$, Risk Ratio 1.045). The standardized hatch date was also significant with increased risk of death as hatch date increased $\left(X^{2}=\right.$ 8.77, $\mathrm{P}=0.0031 \mathrm{~N}=190$, Risk Ratio 1.041). Survival from hatching to 50 days of age was significantly related to the hatching order with risk of death increased for each consecutively hatched chick within an individual brood $\left(X^{2}=4.67, \mathrm{P}=0.0307 \mathrm{~N}=190\right.$ Risk Ratio 1.395). The survival probabilities by order (Kaplan-Meier estimates) show only a marginal effect survival from hatching to 21 days of age (Table 5). Survival probability curves by the order of hatching to age 14,21, and 50 days for Snowy Egrets illustrate survival over time (Fig. 6). 
Table 5. Survival Probabilities (SE) for Brood Size 3 and 4 by Order

\begin{tabular}{|c|c|c|c|c|c|c|}
\hline ORDER & $\begin{array}{l}\text { DAY 14 } \\
(P<0.35)\end{array}$ & $\mathrm{N}$ & $\begin{array}{l}\text { DAY 21 } \\
(P<0.06)\end{array}$ & $\mathrm{N}$ & $\begin{array}{l}\text { DAY 50 } \\
(P<0.14)\end{array}$ & $\mathrm{N}$ \\
\hline A & $\begin{array}{l}0.9259 \\
(0.0356)\end{array}$ & 54 & $\begin{array}{l}0.9216 \\
(0.0376)\end{array}$ & 52 & $\begin{array}{l}0.3610 \\
(0.2615)\end{array}$ & 52 \\
\hline B & $\begin{array}{l}0.8312 \\
(0.0590)\end{array}$ & 55 & $\begin{array}{l}0.8279 \\
(0.0523)\end{array}$ & 53 & $\begin{array}{l}0.6452 \\
(0.3548)\end{array}$ & 56 \\
\hline $\mathrm{C}$ & $\begin{array}{l}0.8093 \\
(0.0690)\end{array}$ & 52 & $\begin{array}{l}0.8014 \\
(0.0540)\end{array}$ & 52 & $\begin{array}{l}0.4239 \\
(0.1627)\end{array}$ & 55 \\
\hline $\mathrm{D}$ & $\begin{array}{l}0.7188 \\
(0.1150)\end{array}$ & 28 & $\begin{array}{l}0.6404 \\
(0.0992)\end{array}$ & 28 & $\begin{array}{l}0.3224 \\
(0.2340)\end{array}$ & 27 \\
\hline
\end{tabular}

Figure 6a. Survival to 14 Days of Age by Order

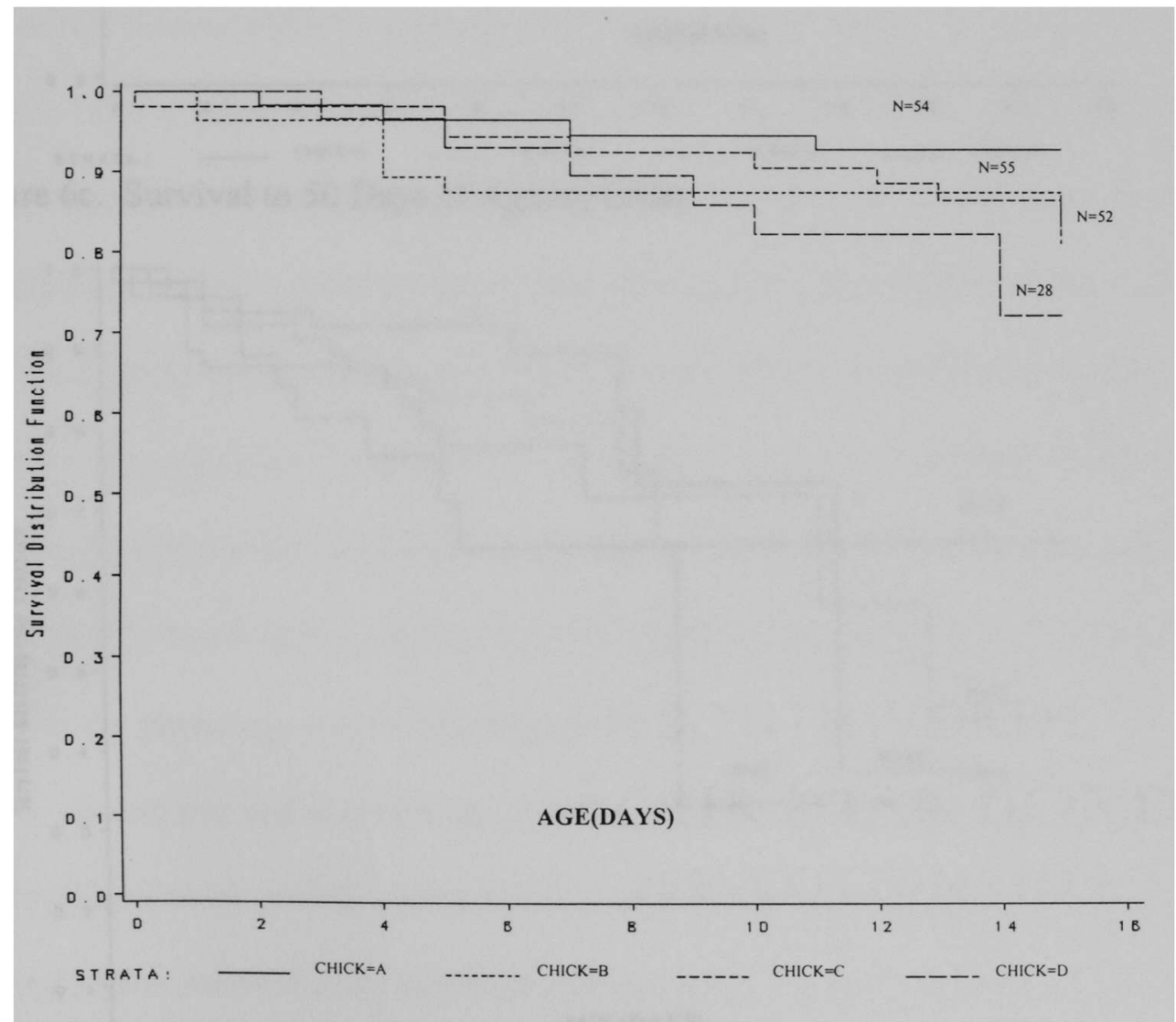


Figure 6b. Survival to 21 Days of Age by Order

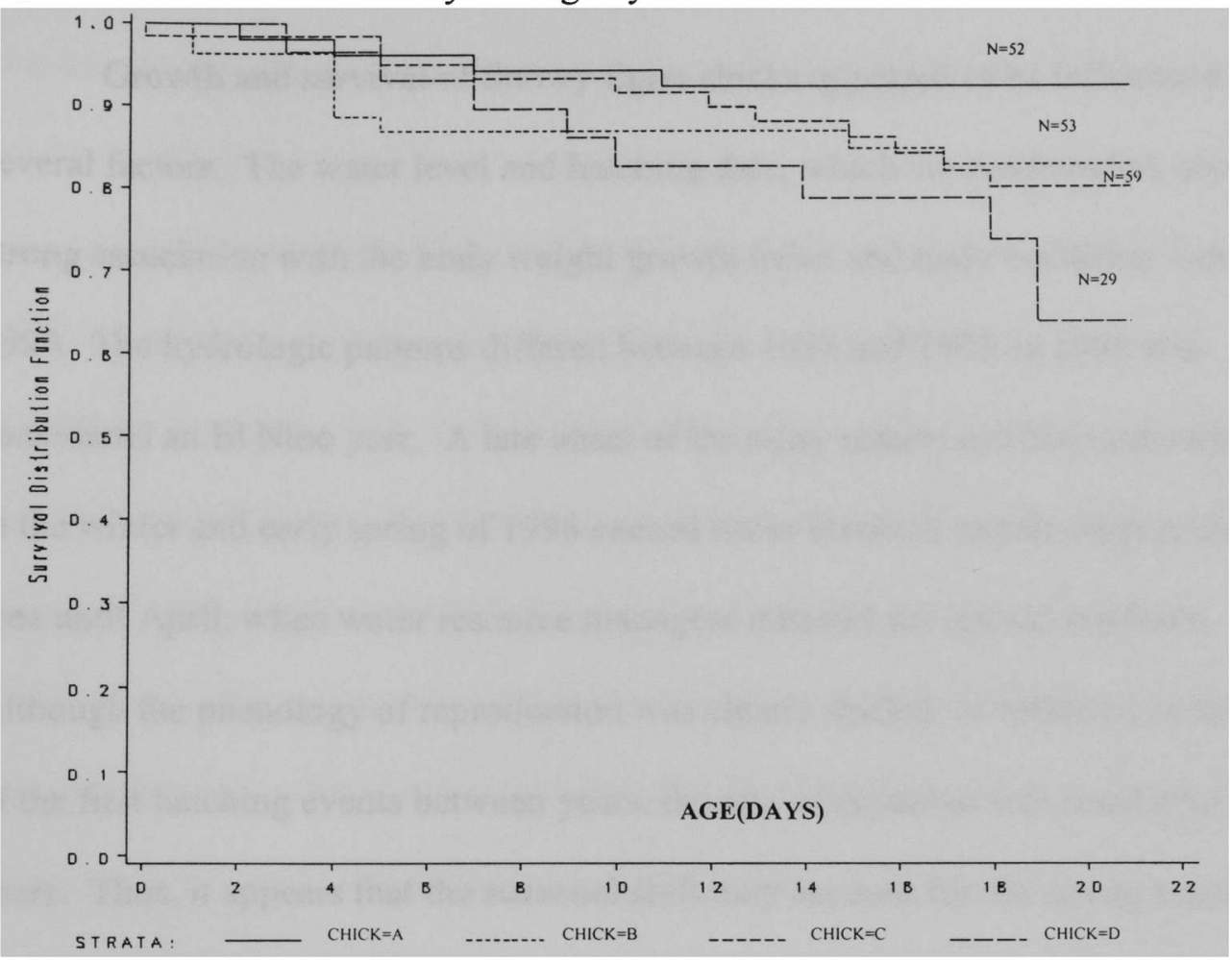

Figure 6c. Survival to 50 Days of Age by Order

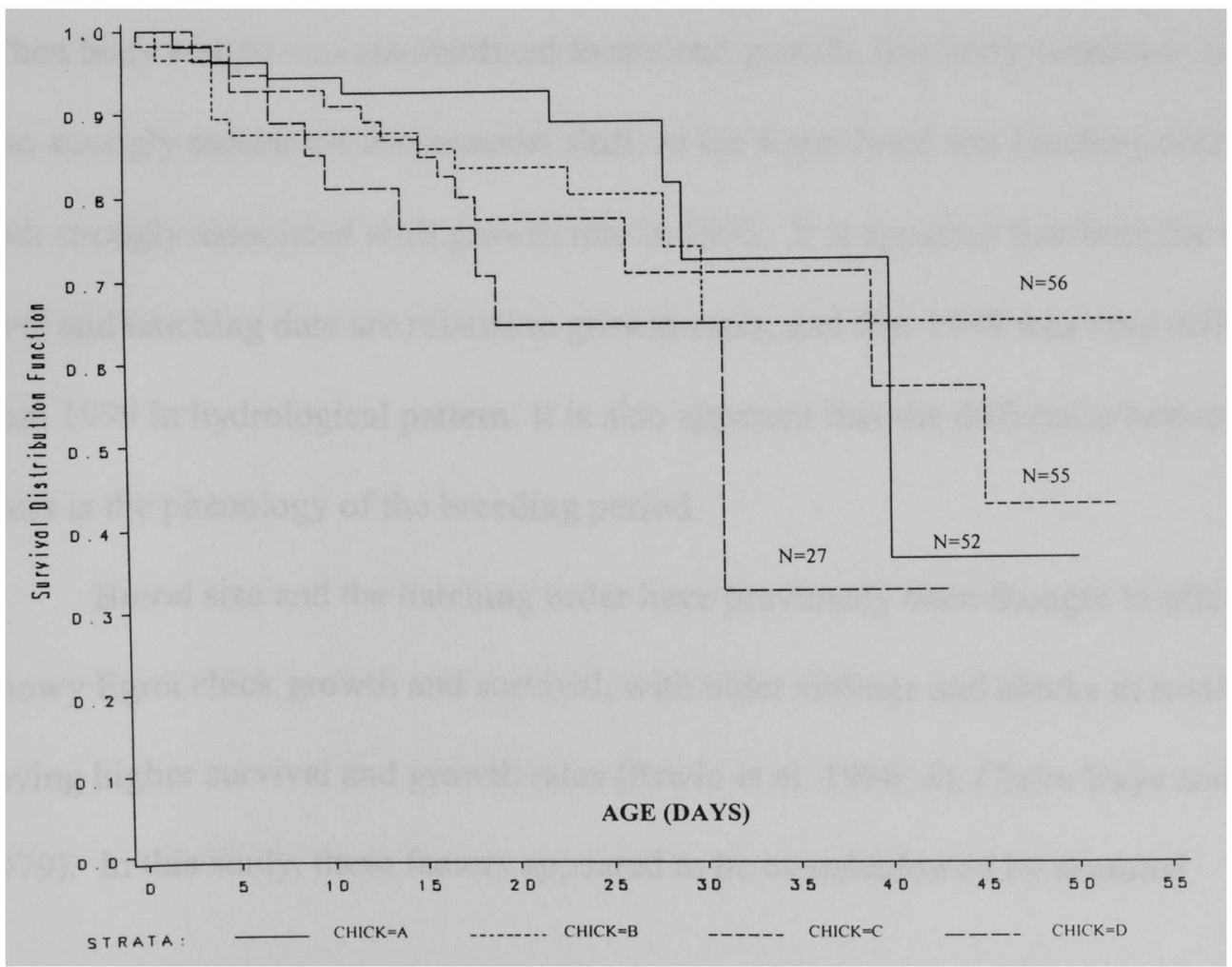




\section{DISCUSSION}

Growth and survival of Snowy Egret chicks appeared to be influenced by several factors. The water level and hatching date, which are confounded, showed a strong association with the body weight growth index and body condition index in 1999. The hydrologic patterns differed between 1998 and 1999 as 1998 was considered an El Nino year. A late onset of the rainy season and heavy precipitation in the winter and early spring of 1998 caused water levels to remain high in the study area until April, when water resource managers initiated the annual drydown. Although the phenology of reproduction was clearly shifted, as reflected in Julian date of the first hatching events between years, the rate of drydown was consistent in both years. Thus, it appears that the seasonal shift may account for the strong association of the water level and hatching date on the body growth index in 1998 but not 1999 . When body weight was standardized to skeletal growth, this body condition index was also strongly associated the seasonal shift, as the water level and hatching date were both strongly associated with growth rate in 1998. It is apparent that both the water level and hatching date are related to growth rates, and that 1998 was very different from 1999 in hydrological pattern. It is also apparent that the difference between the years is the phenology of the breeding period.

Brood size and the hatching order have previously been thought to affect Snowy Egret chick growth and survival, with older siblings and chicks in small broods having higher survival and growth rates (Erwin et al. 1996, St. Claire Raye and Burger 1979). In this study, these factors appeared to be overshadowed by seasonal 
hydrologic conditions. The lack of clear hatching asynchrony in this population may also bear on this discrepancy by shortening or eliminating the hatching interval between siblings.

Asynchronous hatching has been traditionally interpreted as adaptation by which brood size is adjusted to food availability (Lack 1956, Siegfried 1972). The underlying assumption is that all chicks survive when food is readily available, and that "C" and " $D$ " chicks die when food is limited. For example, Forbes et al. (1977) supported the "insurance theory" or replacement of older chicks that die prior to fledging by younger nest mates which would otherwise die. Werschkul (1979) suggests that even when food is abundant, parental birds do not distribute food evenly, and that parental care, not asynchrony, predicts survival within the same brood. When considering the gap between hatch dates within broods in 1999, an interesting pattern emerged. The degree of asynchrony between " $A$ " and "B" chicks was smaller than for "C" and " $D$ " chicks, suggesting that the effect of hatch order may be dampened for "A" and "B" chicks due to lack of asynchronous hatching. The period between hatching days for " $A$ " and "B" chicks seems to be shorter than the period between "B" and "C" chicks, suggesting another mechanism by which the hatching order may affect survival.

This pattern of variable hatching intervals was observed in Little Egrets (Egretta garzetta), a species very similar to Snowy Egrets, in Japan (Inoue 1985). Inoue found " $A$ " and "B" chicks hatched at a 7.7 hour mean interval, while "B" and "C" chicks hatched at a 16.4 hour mean interval, and " $C$ " and " $\mathrm{D}$ " chicks hatched at a 
24.7 hour mean interval. Fujioka (1987) found that in Cattle Egrets brood reduction, commonly attributed to asynchronous hatching, occurs before the period of peak food demand. Further investigation of hatching interval between siblings would result in a better understanding of how the hatching order influences chick growth and survival.

Factors influencing survival rates may have varied as the chicks matured.

Survival to 14 days of age showed little influence by any of the factors under consideration. Chicks hatched early in the season, when the water levels were higher, had higher survival rates for both the 0 to 21 and 0 to 50 day survival intervals.

Younger siblings had lower survival rates than their older siblings for from hatching to 21 days of age and 50 days of age. The water level at hatching and hatching date both strongly influenced survival rates for chicks, especially as they neared independence.

The low survival rate of "A" chicks to day 50 in this study was surprising, but agreed with first year mortality data previously published (Ryder 1978). Erwin (1996) also found reduced survival probabilities in "A" chicks in the interval from 21 to 100 days of age. I did follow more "A" chicks with radio transmitters equipped with mortality sensors, and feel this survival probability is a valid assessment for this study.

The transition from dependent fledgling to independent juvenile is assumed to be one of the most critical periods for avian survival, due to starvation, as juveniles are inefficient foragers (Hirons et al 1979, Newton et al 1982, Richner 1992). The survival rates for the interval from hatching to 50 days of age estimated in this study may reflect the mortality associated with this critical period. It appears that there is more variation within hatching order as the chicks matured than between different 
hatching orders of the same age. Nonetheless, this study falls short of documenting survival rates of recruits to the point of independence from parental birds. The change in survival rates and the effects of the water level, hatching date and hatching order as the chicks grow older points to the importance of monitoring chicks for longer periods of time to fully understand Snowy Egret reproduction. 


\section{LIST OF REFERENCES}

Allison, P. D., 1995. Survival analysis using the SAS system: A practical guide. SAS Institute, Cary, NC.

Arcese, P., and J. N. M. Smith. 1988. Effects of population density and supplemental food on reproduction in song sparrows. J. Anim. Ecol. 57: 119-136.

Baicich, P. J., and C. J. O. Harrison. 1997. Nests, eggs, and nestlings of North American birds. Academic Press.

Bancroft G. T. and S. D. Jewell. 1987. Foraging habitat of Egretta herons relative to stage in the nesting cycle and water conditions, $2^{\text {nd }}$ Annual Report to South Florida Water Management District, West Palm Beach, 174 pp.

Bancroft, G. T., S. D. Jewell, and A. M. Strong. 1990. Foraging and nesting ecology of herons in the lower Everglades relative to water conditions. Final Report. South Florida Water Management District, West Palm Beach, FL.

Beissinger, S. R. and J. E. Takekawa. 1983. Habitat use by and dispersal of Snail Kites in Florida during drought conditions. Florida Field Naturalist 11: 89-106.

Bent, A. C., 1926. Life histories of North American marsh birds. United States National Museum Bulletin No. 135. Smithsonian Institute Press, Washington, DC.

Boutin, S. 1990. Food supplementation experiments with terrestrial vertebrates: patterns, problems, and the future. Can. J. Zool. 68: 203-220.

Cezilly, Frank. 1997. Demographic studies of wading birds: an overview. Colonial Waterbirds 20(1): 121-128.

Cezilly, F., V. Boy, R. E. Green, G. J. M. Hirons and A. R. Johnson. 1995. Interannual variation in greater flamingo breeding success in relation to water levels. Ecology 76:1143-1150.

Custer, T. W., and R. G. Osborn. 1978. Feeding habitat use by colonially-breeding herons, egrets, and ibises in North Carolina. Auk 95: 733-743.

Erwin, R. M., and T. W. Custer. 1982. Estimating reproductive success in colonial waterbirds: an evaluation. Colonial Waterbirds 5: 49-56. 
Erwin, R. M., Haig, J. G., Stotts, D. B., and J. S. Hatfield. 1996. Reproductive success, growth and survival of Black-crowned Night-Heron (Nycticorax nycticorax) and Snowy Egret (Egretta thula) chicks in coastal Virginia. Auk 113: 119-130.

Forbes, S., Thornton, S., Glassey B., Forbes, M.., and N. J. Buckley. 1997. Why parent birds play favorites. Nature 390:351-352.

Frederick, P. C. 1993. Wading bird nesting success studies in the Water Conservation Areas of the Everglades 1992. Final Report. South Florida Water Management District, West Palm Beach, FL.

Frederick, P. C. 1995 . Wading bird nesting success studies in the Water Conservation Areas of the Everglades 1992-1995. Final Report. South Florida Water Management District, West Palm Beach, FL.

Frederick, P. C., and M. W. Collopy. 1988. Reproductive ecology of wading birds in relation to water conditions in the Florida Everglades. Fl. Cooperative Fish and Wildlife Research Unit and University of Florida School of Forestry Resources and Conservation Technical Report, Univ. Florida, Gainesville.

Frederick, P. C. and M. W. Collopy. 1989b. Nesting success of five species of wading birds (Ciconiiformes) in relation to water conditions in the Florida Everglades. Auk 106: 625-634.

Frederick, P. C. and M. G. Spalding. 1994. Factors affecting reproductive success of wading birds (Ciconiiformes) in the Everglades ecosystem in Everglades: The Ecosystem and Its Restoration, S. M. Davis and J. C. Ogden (Eds.), St. Lucie Press, Delray Beach, FL

Fujioka, M. 1984. Asynchronous hatching, growth and survival of chicks of the Cattle Egret Bubulcus ibis. Tori 33:1-12.

Fujioka, M. 1987. Mechanisms and factors of brood reduction in the Cattle Egret Bubulcus ibis. Pp. 115-123 in Animal Societies: Theories and Facts (Ito, Y., Brown, J. L., and J. Kikkawa, eds.). Japan Science Society Press, Tokyo.

Hairston, N. G., Smith, F. E., and L. B. Slobodkin. 1960. Community structure, population control, and competition. Am. Nat. 94: 421-425.

Hirons, G, Hardy, A., and P. Stanley. 1979. Starvation in young Tawny Owls. Bird Study 26:59-63. 
Inoue, Y. 1985. The process of asynchronous hatching and sibling competition in the Little Egret Egretta garzetta. Colonial Waterbirds 8:1-12.

Jenni, D. A., 1969. A study of the ecology of four species of herons during the breeding season at Lake Alice Alachua County, Florida. Ecological Monographs 39:245-270.

Lack, D. 1954. The natural regulation of animal numbers. Oxford University Press, Oxford.

Lack, D. 1956. A swift in a tower. Methuen and Co. Ltd.

Lack, D. 1966. Population studies of birds. Clarendon Press, Oxford.

Lawless, J. F. 1982. Statistical Models for lifetime data. J. Wiley and Sons, NY.

Lebreton, J. D., Pradel, R., and J. Clobert. 1993. The statistical analysis of survival in animal populations. Tree 8: 91-95.

Newton, I., Bell, A., and I. Wyllie. 1982. Mortality of Sparrowhawks and Kestrels. British Birds 75:195-204.

Ogden, J. C. 1978. Population Trends of colonial wading birds on the Atlantic and Gulf coastal plains. Pp. 137-153 in Wading birds (A. Sprunt, IV, J. C. Ogden and S. Winkler, eds.). National Audubon Society Research Report No. 7. New York, New York.

Ogden, J. C. 1994. A comparison of wading bird nesting colony dynamics, 19311946 and 1974-1989, as an indication of changes in ecosystem conditions in the southern Everglades. Pp. 533-570 in Everglades. The ecosystem and its restoration (S. M. Davis and J. C. Ogden, eds.). St. Lucie Press, Delray Beach, Florida.

Richner, H. 1992. The effect of extra food in breeding Carrion Crows. Ecology 73:330-335.

Roberston, W. B., Jr., and J. A. Kushlan. 1974. The southern Florida avifauna. Pp. 414-452 in Environments of south Florida past and present (P. Gleason, ed.). Memoir 2, Miami Geological Society, Miami, Florida.

Ryder, R. A., 1978. Breeding Distribution, Movements, and Mortality of Snowy Egrets in North America. Pp. 197-205 in Wading Birds (A. Sprunt, IV, J. C. Ogden, and S. Winckler, Eds.). National Audubon Society Research Report No. 7. 
SAS Institute, Inc. 1994. SAS/STAT user's guide release 6.10. SAS Institute, Inc., Cary, NC.

Scott, W. E. D. 1887. The present condition of some of the bird rookeries of the Gulf coast of Florida. Auk 4:135-144, 213-222, 273-284.

Siegfried, W. R. 1972. Breeding success and reproductive output of the Cattle Egret. Ostrich 43:43-55.

St. Clair Raye S. and J. Burger. 1979. Behavioral determinants of nestling success of Snowy Egrets (Leucophoyx thula).

Strong, A. M., Bancroft, G. T., and S. D. Jewell. 1997. Hydrological constraints on Tricolored Heron and Snowy Egret resource use. Condor 99:894-905.

Sprunt, A., Jr. 1954. Florida bird life. Coward-McCann, Inc. New York, New York.

Weins, J. A., 1977. On competition and variable environments. Am. Sci. 65: 590-597.

Werschkul, D. F. 1979. Nestling mortality and the adaptive significance of early locomotion in the Little Blue Heron. Auk 96:116-130. 